\title{
Faktor-Faktor yang Berhubungan dengan Pencegahan Anemia pada Remaja Putri di SMA Negeri 4 Kota Jambi Tahun 2018
}

\author{
Nurbaiti \\ Prodi D IIIKebidanan, Sekolah Tinggi IImu Kesehtan Baiturrahim Jambi \\ e-mail : nbaiti812@gmail.com
}

\begin{abstract}
Anemia is one of the health problems throughout the world, especially developing countries, which is estimated that $30 \%$ of the world's population suffer from anemia. Anemia often occurs in adolescents and pregnant women. Anemia in young women is still quite high, according to the World Health Organization (WHO 2013). This study aims to determine the relationship of knowledge, the role of the family, the role of health workers and information media with the prevention of anemia and can be used as information in SMAN 4 Kota Jambi. Anemia is a condition in which the reduction of red blood cells (erythrocytes) in the blood circulation or hemoglobin mass so that it is unable to fulfill its function as an oxygen carrier network. This research was conducted at SMAN 4 Kota Jambi, this research is a quantitative research using descriptive method and with proportional random sampling random sampling technique. The population in this study were all adolescents of class $X$ and XI in SMAN 4 Jambi City totaling 826 people and the sample in this study were 124 students from SMAN 4 Kota Jambi.his research was conducted for one semester in 2018 and then analyzed by univariate, bivariate and multivariate. Based on the results of the bivariate analysis, it was found that there were 4 independent variables related to prevention of anemia in adolescent girls, namely knowledge $(p$-Value $=0.004)$, family role $(p$-Value $=0.021)$, role of health workers ( $p$-Value 0.017), and media information ( $p$-Value 0,000). The most dominant information media variable is related to pen preventionna nameia, the advice given to high schools to cooperate with the puskesmas to provide information to young women in SMAN 4 Jambi City regarding the prevention of anemia.
\end{abstract}

Keywords:

prevention of anemia; information; family roles; Knowledge ; the role of health workers

\section{PENDAHULUAN}

Anemia merupakan salah satu masalah kesehatan di seluruh dunia terutama Negara berkembang yang diperkirakan $30 \%$ penduduk dunia menderita anemia. Anemia banyak terjadi pada remaja dan ibu hamil.Anemia pada remaja putri sampai saat ini masih cukup tinggi, menurut.World Health Organization (WHO 2013), prevalensi anemia dunia berkisar 40-88 $\%$. Jumlah usia remaja (10-19 tahun) di Indonesia sebanyak $26,2 \%$ yaitu terdiri dari $50,9 \%$ laki-laki dan $49,1 \%$ perempuan (Choiriya,2015).

Menurut data hasil Riskesdas tahun 2013, prevalensi anemia di Indonesia yaitu 21,7\% dengan penderita anemia berumur 5-14 tahun sebesar $26,4 \%$ dan $18,4 \%$ penderita berumur 15-24 tahun (Kemenkes RI,2014). Data Survei Kesehatan Rumah Tangga (SKRT) tahun 2012 menyatakan bahwa prevalensi anemia pada balita sebesar $40,5 \%$, ibu hamil sebesar $50,5 \%$, ibu nifas sebesar $45,1 \%$, remaja putri usia $10-18$ tahun sebesar $57,1 \%$ dan usia 19-45 tahun sebesar $39,5 \%$. Wanita mempunyai resiko terkena anemia paling tinggi terutama pada remaja putri.

Faktor lain yang dapat menyebabkan anemia adalah asupan zat gisi yang tidak adekuat yaitu kebiasaan mengkonsumsi makanan yang dapat mengganggu penyerapan zat besi seperti teh atau kopi yang bersamaan waktu makan, dan kurangnya pengetahuan tentang anemia, sikap yang tidak mendukung, pendidikan ibu maupun tingkat sosial ekonomi keluaraga.

Remaja putri sering menderita anemia karena masa remaja masa pertumbuhan yang sangat membutuhkan zat gizi lebih tinggi. Selain itu remaja juga mengalami menstruasi setiap bulan dan kurangnya asupan zat besi pada makanan yang dikonsumsi setiap hari.Dampak dari anemia pada remaja putri antara lain, meurunkan daya tahan tubuh sehingga mudah terkena penyakit, menurunkanya aktivitas dan prestasi belajar di samping itu remaja yang mengalami anemia kebugaran juga menurun, sehingga menghambat prestasiolahraga dan produksivitasnya, selain itu masa remaja merupakan masa pertumbuhan yang sangat cepat, kekurangan zat besi pada masa ini merupakan tidak tercapainya tinggi badan yang optimal. Peran tenaga kesehatan sangat penting untuk peningkatan kesehatan remaja melalui pemberian informasi kesehatan secara jelas kepada msyarakat khususnya pada remaja tentang anemia.

Penelitian ini bertujuan untuk melihat apakah ada hubungan antara pengetahuan, peran keluarga, peran tenaga kesehatan dan media informasi dengan pencegahan anemia

\section{METODE PENELITIAN}

Jenis penelitian ini merupakan penelitian kuantitaf dengan desain deskriptif analitik dengan rancangan cross secseonal yaitu pengukuran dengan variabel-variabel yang 
diteliti dilakukan pada saat yang sama. Tempat Penelitian ini dilaksanakan di SMAN 4 Kota Jambi penelitian ini di laksanakan selama 6 bulan. Populasi Penelitian ini adalah semua remaja putri di SMAN 4 Kota Jambi berjumlah 826 siswi, pengambilan sampel dalam penelitian ini menggunakan teknik propesional stratifiet random sampling berjumlah 124 responden. Analisis yang digunkanan analisis univariat, bivariate dan multivariate.

\section{HASIL DAN PEMBAHASAN Analisa univariat}

Tabel.1 Distribusi Frekuensi Varabel bebas dan variabel terikat di SMAN 4 Kota Jambi Tahun 2018

\begin{tabular}{lll}
\hline Variabel & $\mathrm{F}$ & $\%$ \\
\hline Pengetahuan & & \\
Kurang & 27 & 21,8 \\
Cukup & 47 & 37,9 \\
Baik & 50 & 40,3 \\
Peran Keluarga & & \\
\hline
\end{tabular}

\begin{tabular}{lll} 
Kurang & 56 & 45,2 \\
Baik & 68 & 54,8 \\
$\begin{array}{l}\text { Peran Tenaga Kesehatan } \\
\text { Kurang }\end{array}$ & 61 & 49,2 \\
$\begin{array}{l}\text { Baik } \\
\text { Media Informasi }\end{array}$ & 63 & 50,8 \\
$\begin{array}{l}\text { Ada } \\
\text { Tidak ada }\end{array}$ & 74 & 59,7 \\
PencegahanAnemia & 50 & 40,3 \\
Kurang & & \\
Baik & 43 & 34,7 \\
Total & 81 & 65,3 \\
& $\mathbf{1 2 4}$ & $\mathbf{1 0 0}$ \\
\hline
\end{tabular}

Sebagian

besar

responden berpengetahuan baik sebanyak $40,3 \%$, peran keluarga yang baik sebanyak $54,8 \%$, peran tenaga kesehatan yang baik sebanyak 50,8\%, yang mendapat informasi dari media informasi sebanyak $59,7 \%$ dan yang melakukan pencegahan anemia sebanyak $65,3 \%$

\section{Analisis Bivariat}

Tabel 2 Tabulasi silang antara variabel bebas dengan variabel terikat

\begin{tabular}{|c|c|c|c|c|c|c|c|}
\hline \multirow{3}{*}{ Variabel } & \multicolumn{4}{|c|}{ Pencegahan anemia } & \multicolumn{2}{|c|}{ Jumlah } & \multirow[t]{2}{*}{ P-Value } \\
\hline & \multicolumn{2}{|c|}{ Kurang } & \multicolumn{2}{|l|}{ Baik } & & & \\
\hline & $\mathrm{n}$ & $\%$ & $\mathrm{~N}$ & $\%$ & $n$ & $\%$ & 0,002 \\
\hline \multicolumn{7}{|l|}{ Pengetahuan } & \\
\hline Kuranag & 17 & 63 & 10 & 37 & 27 & 100 & \\
\hline Cukup & 13 & 27,7 & 34 & 72,3 & 47 & 100 & \\
\hline Baik & 13 & 26 & 37 & 74 & 50 & 100 & \\
\hline \multicolumn{6}{|l|}{ Peran keluarga } & & 0,021 \\
\hline Kurang & 26 & 46,4 & 30 & 53,6 & 56 & 100 & \\
\hline Baik & 17 & 25 & 51 & 37 & 68 & 100 & \\
\hline \multicolumn{7}{|c|}{ Peran tenaga kesehatan } & 0,017 \\
\hline Kurangb & 28 & 45,9 & 33 & 54,1 & 61 & 100 & \\
\hline Baik & 15 & 23,8 & 48 & 76,2 & 63 & 100 & \\
\hline \multicolumn{7}{|l|}{ Media informasi } & 0,000 \\
\hline Tidak ada & 41 & 82 & 9 & 18 & 50 & 100 & \\
\hline Ada & 2 & 2,7 & 72 & 97,3 & 74 & \begin{tabular}{|l|}
100 \\
\end{tabular} & \\
\hline
\end{tabular}

Hasil analisis hubungan antara pengeetahuan dengan pencegahan anemia hasil Uji statistik di peroleh $\rho=0,002$ karena $p$ value $=$ $0,002<$ a 0,05 maka dapat disimpulkan bahwa secara statistik pada alpa $5 \%$ ada hubungan yang signifikan antara pengetahuan dengan pencegahan anemia di SMAN 4 Kota Jambi.

Hasil analisis hubungan antara peran keluarga dengan pencegahan anemia. Dari hasil Uji statistik di peroleh $\rho=0,021$, karena $p$ value $=$ $0,021<\alpha \quad 0,05$ maka dapat disimpulkan bahwa secara statistik pada alpa $5 \%$ ada hubungan yang signifikan antara peran keluargadengan pencegahan anemia di SMA 4 Kota Jambi

Dari analisis di dapat OR : 2.600 artinya peran keluarga yang baik mempunyai kecendrungan 2.600 kali melakukan pencegahan di banding remaja yang tidak melakukan pencegahan
Hasil analisis hubungan antara peran tenaga kesehatan dengan pencegahan anemia Dari hasil Uji statistik di peroleh $\rho=0,017$, karena $p$ value $=0,017<\alpha 0,05$ maka dapat disimpulkan bahwa secara statistik pada alpa $5 \%$ ada hubungan yang signifikan antara peran tenaga kesehatan dengan pencegahan anemia di SMA 4 Kota Jambi..

Dari analisis di dapat OR : 2,715 artinya peran keluarga yang baik mempunyai kecendrungan 2,715 kali remaja melakukan pencegahan di banding remaja yang tidak melakukan pencegahan

Hasil analisis hubungan antara media informasi dengan pencegahan anemia Dari hasil Uji statistik di peroleh $\rho=0,000$, karena $p$ value $=$ $0,000<\alpha \quad 0,05$ maka dapat disimpulkan bahwa secara statistik pada alpa $5 \%$ ada hubungan yang signifikan antara media informasi dengan pencegahan anemia di SMA 4 Kota Jambi. 
Dari analisis di dapat OR : 164,000 artinya remaja yang mendapat informasi dari media mempunyai kecendrungan 164,000 kali melakukan pencegahan di banding remaja yang tidak melakukan pencegahan

Analisis Multivariat Varibel media informasi setelah dilakukan analisis multivariate dan setelah diseleksi dengan variabel independen lainnya tetap mempunyai hubungan yang bermakna secara statistic, dimana OR : $442,479(95 \% \mathrm{Cl}: 48,328-4051,192) \mathrm{p}=0,000$ memberikan interpretasi bahwa responden yang ada media informasi berpeluang 442,479 kali dalam pencegahan anemia dibandingkan dengan responden yang tidak ada media informasi setelah diseleksi dengan variabel pengetahuan. Artinya dalam hal ini variabel media informasi bersama-sama (Simultan) dengan variabel pengetahuan mempengaruhi pencegahan anemia..

\section{Pembahasan \\ Hubungan pengetahuan dengan pencegahan anemia}

Hasil analisis hubungan antara pengeetahuan dengan pencegahan anemia. hasil Uji statistik di peroleh $\rho=0,002$ karena $p$ value $=0,002<\alpha 0,05$ maka dapat disimpulkan bahwa secara statistik pada alpa 5\% ada hubungan yang signifikan antara pengetahuan dengan pencegahan anemia di SMAN 4 Kota Jambi tahun 2018. Sebelum mengadopsi prilaku baru didalam diri seseorang terjadi proses adaptasi dimana subjek melakukan prilaku yang sesuai dengan pengetahuan yang dimiliki. Berdasrkan hasil penelitian hubungan antara kedua variabel berikut searah artinya baik tingkat pengetahuan tentang anemia maka semakin baik juga perilaku pencegahan pada remaja putri di SMAN 4 Kota Jambi Tahun 2018.

Penelitian ini sejalan dengan penelitian Rusidah (2012) dengan uji kendall tau yang menunujukan $p$-value sebesar 0,000 yang menyatakan ada hubungan antara pengetahuan dengan prilaku pencegahan anemia dalam penelitian tersebut dinyatakan dalam pengetahuan yang berbeda sangat bermakna terhadap terjadinya perubahan perilaku pencegahan anemia

\section{Hubungan peran keluarga dengan pencegahan anemia}

Hasil analisis hubungan antara peran keluarga dengan pencegahan anemia dari 56 responden yang peran keluarga kurang baik ada sebanyak 30 orang (53.6\%) yangmelakukan pencegahan anemia. Dari 68 responden peran keluarga baik sebanyak 51 orang $(75.0 \%)$ yang melakukan pencegahan anemia.Dari hasil Uji statistik di peroleh $\rho=0,021$, karena $p$ value $=$ $0,021<\alpha$ 0,05 maka dapat disimpulkan bahwa secara statistik pada alpa $5 \%$ ada hubungan yang signifikan antara peran keluarga dengan pencegahan anemia di SMAN 4 Kota Jambi

Hasil ini sesuai dengan hasil penelitian Setyowati (2017) menunjukan bahwa sebagian besar responden mendapat dukungan dari keluarga dalam pencegahan anemia dengan uji Chi-Square diproleh P-Value 0,026 yang berarti ada hubungan yang bermakna antara dukungan keluarga dengan perilaku pencegahan anemia.Pada umumnya remaja membutuhkan dukungan dari keluarga yang memberikan pengaruh yang bermakna pada tindakan pencegahan terhadap anemia.

\section{Hubungan peran tenaga kesehatan dengan pencegahan anemia}

Hasil analisis hubungan antara peran tenaga kesehatan dengan pencegahan anemia dari 61 responden yang peran tenaga kesehatan kurang ada sebanyak 33 orang (54.1\%) yangmelakukan pencegahan anemia.

Dari 63 responden peran tenaga kesehatan baik sebanyak 48 orang (76.2\%) yang melakukan pencegahan anemia. Dari hasil Uji statistik di peroleh $\rho=0,017$, karena $p$ value $=$ $0,017<\alpha 0,05$ maka dapat disimpulkan bahwa secara statistik pada alpa $5 \%$ ada hubungan yang signifikan antara peran tenaga kesehatan dengan pencegahan anemia di SMAN 4 Kota Jambi.

\section{Hubungan media informasi dengan pencegahan anemia}

Hasil analisis hubungan antara media informasi dengan pencegahan anemia dari 50 responden yang tidak ada media informasi sebanyak 9 orang (18.0\%) yangmelakukan pencegahan anemia. Dari 74 responden yang ada media informasi sebanyak 72 orang (97.3\%) yang melakukan pencegahan anemia. Dari hasil Uji statistik di peroleh $\rho=0,000$, karena $p$ value $=$ $0,000<\alpha 0,05$ maka dapat disimpulkan bahwa secara statistik pada alpa $5 \%$ ada hubungan yang signifikan antara media informasi dengan pencegahan anemia di SMAN 4 Kota Jambi.

Menurut penelitian arwin (2017) menyatakan bahwa ada pengaruh pemberian media informasi berupa poster tentang pencegahan anemia dengan perubahan perilaku pencegahan anemia dengan hasil uji paired $t$ test terdapat selisih antara pre test dan post test dengan rata-rata perilaku sebelum perlakuan yaitu 48,13 dan setelah perlakuan 61,20 , standar deviasi sebesar 1,5999 pada pre test dan 1,6006 pada posttest dengan p-value 0.00010 dimana kurang dari batas kritis penelitian 0,05 sehingga keputusan hipotesis adalah terdapat perbedaan bermakna antara perilaku ibu hamil pre test dan perilaku ibu hamil setelah post test. 
Notoatmodjo (2010) menyatakan bahwa ada atau tidak adanya informasi mengenai kesehatan atau fasilitas kesehatan akan mempengaruhi perilaku seseorang terhadap fasilitas kesehatan. Semakin sering diberikan informasi akan terjadi perubahan perilaku yang bersifat tetap

\section{SIMPULAN}

Setelah dilakukan penelitian hubungan pengetahuan, peran keluarga, tenaga kesehatan dan media informasi dengan pencegahan anemia pada remaja putri di SMAN 4 Kota Jambi Tahun 2018, yang dilakukan secara analisis multivariat dengan uji statistic Chi Square maka dapat di simpulkan

1. Ada hubungan yang signifikan pengetahuan remaja putri secara parsial dengan perilaku pencegahan anemia di SMAN 4 Kota Jambi Tahun 2018

2. Ada hubungan yang signifikan peran keluarga remaja putri secara parsial dengan pencegahan anemia pada remaja putri tahun 2018

3. Ada hubungan yang signifikan peran keluarga secara parsial dengan pencegahan anemia pada remaja putri di SMAN 4 Kota Jambi tahun 2018

4. Ada hubungan yang signifikanmedia informasi dengan pencegahan anemia pada remaja putri di SMAN 4 Kota Jambi tahun 2018.

5. Variabel yang dominan berhubungan dengan pencgahan anemia $\mathrm{m}$, adalah media informasi di SMAN 4 Kota Jambi tahun 2018

\section{DAFTAR PUSTAKA}

Amrullah, 2011.Hemoglobin (Kadar, Struktur, Cara Mengukur, DII). Terdapatdalam http://.uin-malang.ac.id

Arikunto, S. 2006. Prosedur Penelitian Suatu Pendekatan Praktik (Edisi Revisi). Rineka Cipta. Jakarta

Arisman. 2004. Gizi Dalam Daur Hidup. EGC : Jakarta.

Ariyanto. 2008. Sosiologi Untuk Kesehatan. Jakarta:Selemba Medika

Arwin Arminiati, 2017,pengaruh poster pencegahan anemia terhadap perilaku dan kadar ibu hamil di wilayah kerja puskesmas baki sukoharjo.Fakultas ilmu kesehatan

UMS.http://eprints.ums.ac.id/51193/15/NA SKAH\%20PUBLIKASI.pdf

Aqip Zainal.2009. Belajar dan Pembelajaran di Sekolah Dasar.Yrama Widya. Bandung.

Badan Penelitian dan Pengembangan Kesehatan Kementerian Kesehatan RI.. Riset Kesehatan Dasar (Riskesdas) 2013. Jakarta. 2013
Choiriyah, Endar Wahyu. 2015. Hubungan Tingkat Asupan Protein, Zat Besi dan Vitamin C Dengan Kejadian Anemia Pada Remaja Putri Kelas X dan XI SMA Negri 1 Polokarto Kabupaten Sukoharjo.

http://eprints.ums.ac.id/39695/1/NASKAH\%20P UBLIKASI.pdf

Departemen Gizi dan Kesehatan Masyarakat, FKM UI, 2014.Gizi Dan Kesehatan Masyarakat. Raja Grafindo Persada, Jakarta.

Dinas Kesehatan Kota Jambi, 2015.Data anemia remaja tahun 2015.2016 dan 2017

Dinkes, Indragirihulu,2016http://dinkes.inhukab.g o.id/puskesmas-lirik/2016/08/12/tablettambah-darah-pada-siswi-smp-dan-smapada-pemberian-remaja-putri/.tablet

Gielen, A.C. dan Mc Donald E.M., 2008, The Preceed-Proceed Planning Model, Jossey Bass, California.

Huda,Syamsul(2009)."Penyebab Anemia" Diakses Tanggal 19 April 2017

http://skp.unair.ac.id/repository/web.pdf/web AN EMIA SYAMSUL HUDA.2009pdf

Hastono, S.P. 2011. Statistik Kesehatan, Rajawali Pers, Jakarta.

Hutahean. 2009. Asuhan Keperawatan Maternitas. Jakarta:Selemba Medika

Induniasih dkk.2016.Promosi Kesehatan Pendidikan Kesehatan Dalam Keperawatan.Pustaka Baru Press. Yogyakarta

Kemenkes.RI,2014. Standar Tablet Tambah Darah Bagi Usia Subur dan Ibu Hamil.Jakarta

Kemenkes RI,2015. Pedoman Penatalakasanaan Pemberian Tablet Tambah

Darah,Jakarta

Kusmiran, Eny. 2012. Kesehatan Reproduksi Remaja Dan Wanita. Jakarta : Selemba Medika

Nur Asri, 2013. Hubungan peran Petugas Kesehatan dan media Informasi Dngan Perilaku seksual pada ibu Pasca Nifas Di Wilayah Kerja Puskesmas Peukan Bada Kabupaten Aceh Besar.Sekolah Tinggi IImu Kesehatan U'Budiyah.http://simtakp.uui.ac.id/dockti/N UR ASRI-skripsi nur asri.pdf

Nurarif H. Amin \& Kusuma Hardi.2013. Aplikasi Asuhan Keperawatan Berdasarkan Diagnosa Medis \& NANDA (North American Nursing Diagnosis Association) NIC-NOC. Mediaction Publishing

Notoatmojo, Soekidjo. 2010. Promosi Kesehatan Teori dan Aplikasi.Jakarta : Rineka Cipta

Notoatmodjo, S., 2010, IImu Perilaku Kesehatan, Rineka Cipta, Jakarta.

Notoatmodjo Soekidjo, 2003.IImu Kesehatan Mayarakat Jakarta, Rineka Cipta. 
Notoamodjo Soekidjo,2005, Metode Penelitian Kesehatan, Rineka Cipta

Novita Dkk.2016.Promosi Kesehatan Untuk Maahasiswa Kebidanan, Trans Info Media.Jakarta.

Martini, 2015.Faktor _ faaktor yang Berhubungan Dengan Kejadian Anemia pada Remaja Putri Di MAN 1 Metro. Program Studi Kebidanan Metro Polteknik Taniung Karang.

Mona dkk.2015.Perundang - Undangan Kesehatan dan Kesehatan Jiwa.Pustaka Mahardika.Yogyakarta

Mubarak, Wahit. 2012. Promosi Kesehatan untuk Kebidnan.Jakarta : Salemba Mediak.

Michael J.2008.Gizi Kesehatan Mayarakat.EGC.Jakarta

Potter, P. A., \& Perry, A. G. (2009).Buku Ajar Fundamental : konsep, proses, dan praktik. Jakarta : EGC

Priscilla L dkk. 2016.Buku Ajar Keperawatan Medikal Bedah.EGc.Jakarta

Proverawati, Asfuah, 2010. IImu Gizi Untuk Keperawatan Dan Gizi Kesehatan.Nuha Medika : Yogyakarta

Price Sylvia.2006.Patofisiologi Konsep Klinik Proses-Proses Penyakit.Edisi.EGC.jakarta

Prawihardjo,Sarwono, 2006. Pelayanan Kesehatan Maternal dan Neonatal,

Yayasan Bina Pustaka Sarwono Prawihardjo : Jakarta.

Setyowati, dkk, 2017. Faktor-Faktor Yang Berhubungan Dengan Perilaku Makan Remaja Putri Dalam Pencegahan Anemia Di Wilayah Kerja Puskesmas Ngemplak Simongan

Solang S dkk,2016, Promosi Kesehatan Untuk Mahasiswa Kebidanan,In Media.Bogor

Sibagariang. 2010. Kesehatan Reproduksi Wanita. Jakarta : Trans Info Media.

Supariasa. I made.Nyoman.dkk.2001.Penilaian Status Gizi.Jakarta:EGC

Tarwoto.2008. Kesehatan Usia Lanjut dengan Pendekatan Asuhan Keperawatan. Jakarta: Jakarta Salemba

Varney Helen, 2001. Asuhan Kebidanan. EGC : Jakarta

Winarno, F.G (2010). Kimia Pangan dan Gizi. Jakarta: Gramedi

Widyastuti, Dkk. 2009.Kesehatan Reproduksi, Yogyakarta : Fitramaya

Zainudi Ali.H. 2009. Pengntar Keperawatan Kleuarga. EGC.Jakarata 